\title{
Farmers' Willingness as Well as Its Compensation Strategy to Prevent and Control Agricultural Non-Point Source Pollution in Water Source Areas-Based on a Comparative Analysis of Pesticide and Fertilizer Inputs
}

\author{
Jie $\operatorname{Lin}^{1 *}$, Jianlin $\operatorname{Pan}^{2}$ \\ ${ }^{1}$ School of Economics and Management, Zhejiang University of Water Resources and Electric Power, Hangzhou 310018, \\ China \\ ${ }^{2}$ School of Economics and Management, YiWu Industrial \& Commercial College, Yiwu 322000, China
}

Corresponding Author Email: linj@zjweu.edu.cn

https://doi.org/10.18280/ijsdp.150817

Received: 1 July 2020

Accepted: 15 September 2020

Keywords:
agricultural non-point source pollution,
pesticides, fertilizers, ecological
compensation

\begin{abstract}
This paper took the voluntary pesticide and fertilizer reduction ratios of the farmers as the substitute variables for farmers' willingness to prevent and control the agricultural non-point source pollution. Then, the paper adopted an improved double-bounded dichotomous choice (DBDC) to obtain farmers' voluntary pesticide and fertilizer reduction ratios and the corresponding compensation attitudes of the farmers. The research found that, in contrast to fertilizers, pesticides are a stronger output-related factor for farmers, and any reduction in pesticides would cause great output fluctuations. After the influencing factors of the farmers' compensation attitude towards pesticide and fertilizer reduction were subject to ordinal regression analysis, the main influencing factors of farmers' compensation attitude towards fertilizer and pesticide reduction were obtained respectively, which had further proved that for farmers, compared with pesticides, the risk of fertilizer reduction is lower, and their attitudes are quite different, but as long as the compensation is sufficient, they are willing to take more stringent measures.
\end{abstract}

\section{INTRODUCTION}

Nowadays, the global freshwater demand has been on the rise, but various factors such as population growth, water pollution, economic development, land use changes, and future climate changes have brought uncertainties to the availability of freshwater resources [1]. Among these factors, the pollution of agricultural non-point sources has accumulated over the years and become increasingly apparent in recent years. Survey showed that, in China, the annual chemical fertilizer consumption is 6535.34 tons; the pesticide consumption is 138.96 tons; the daily domestic sewage discharge is 1106 tons, and daily garbage produce is 73.62 tons, and these pollutants are destroying the local ecological environment and causing typical agricultural non-point source pollution [2]. The watershed is dynamic in space and time, and the change of any single component will affect the entire watershed [3]. Now, more and more evidences show that it is impossible to fundamentally solve water pollution problem without controlling the pollution of agricultural non-point sources.

Academic research concerning the impact of cultivated land use behaviors on the ecological environment mainly uses the fertilizer and pesticide usage amount to measure their impact on ecological environment, and it's believed that the chemicals that had been input in agricultural production are the main source of non-point source pollution [4]. The ecological production behaviors of farmers have both the effects of environmental pollution control and resource recycling [5].
However, as the subjects and stakeholders of ecological production behaviors, the response of farmers is not active at all [6]. When selecting measures to achieve good ecological status, the most widely used method is the cost-benefit analysis [7]. Obviously, it is not comprehensive to analyze the behaviors of farmers only from the perspective of the rationaleconomic man, because when making production decisions, the farmers are not only affected by cost-effective economic incentives and the principle of maximizing profit, but also by other factors, such as their social attributes like values and attitudes [8, 9], local perceptions [10], ecological agriculture modes [11], their enthusiasm for adopting green production technologies, smallholder social service organizations [11], environmental education [12], and consumer preferences [13], etc.

At the same time, as a financial incentive mechanism which can convert external, non-market environmental values into ecological services (ES) and provide ES to local participants, the ecological compensation has received wide attention from the entire society [14]. An assessment of China found that almost all ES from 2000 to 2010 had produced positive socioeconomic benefits [15]. The basic principle behind ecological compensation is that it can urge decision makers to give more considerations to ecosystems and biodiversity [16]. Besides some early discussions on the capital sources and standards of ecological compensation, scholars have begun to explore how to improve the compensation efficiency, and they found that there are many obstacles hindering the such efforts such as the understanding of interest relations [17], the 
regional differences in farmers' willingness to participate in farmland ecological compensation [18], the response of farmers to the farmland ecological compensation policies and the diversity of the means of livelihoods [19, 20], and the response of farmers to technological knowledge and compensation policies [21], etc. And the causes of these obstacles are: first, the unsatisfactory effects of technology application make the farmers resistant to the compensation policies [22]; second, the existing compensation policies haven't taken into account the recipients' willingness to receive compensation, the recipients' payment ability, and the regional differences [23]. Since farmers are the direct targets of compensation policies, scholars believed that figuring out the inherent needs and preferences of farmers for the compensation policies is an important guarantee for related policies to gain supports $[24,25]$. Therefore, the future compensation policies should be formulated combining with the preferences of farmers.

To sum up, in terms of the willingness of farmers engaged in conservation tillage, most existing studies only focus on the use of a certain type pesticide or fertilizer. However, to measure the ecological farming behaviors of farmers more scientifically, the use behaviors of pesticides and fertilizers should be considered comprehensively. In addition, the research angles of relevant studies are not as varied, most of them had only focused on whether the farmers have the willingness to accept conservation tillage and the decisive factor in it; they seldom researched the ES-value compensation willingness for conservation tillage, such as the willingness to pay, the payment level, the willingness to accept compensation, and the compensation level, etc. In view of this, this paper incorporated pesticides and fertilizers into the analysis framework at the same time; based on the perceptions of farmers, the concepts of strong output correlation and weak output correlation were introduced in the paper to investigate the willingness and support conditions of farmers to adopt certain ecological protection measures in a complex decisionmaking environment.

\section{SURVEY DESIGN}

\subsection{Survey site and objects}

The survey site is the Liangnong Town, which locates in the area of the water source protection zones of Siminghu Reservoir, Zhejiang province, China. The Siminghu Reservoir has a total catchment area of 103.1 square kilometers (93 square kilometers of which is under the jurisdiction of Liangnong Town), and a total storage capacity of 123 million cubic meters. It is a large-scale reservoir built for multiple purposes such as irrigation, flood control, water supply, power generation, and fish farming. According to statistics, in 2019 Liangnong Town accommodated 9815 agricultural households with an agricultural population of 30430 people; the total sown area was $20,880 \mathrm{mu}$; the area of multiple cropping was $11,360 \mathrm{mu}$ in the current year, wherein the sown area of rice was $8211 \mathrm{mu}$, accounting for $39.32 \%$, and rice was the mostly widely planted crop in that year, therefore, this study chose rice growers as the survey objects.

\subsection{Survey content, method and key steps}

The survey content included four parts: a. basic information of farmers; b. farmers' willingness to prevent and control agricultural non-point source pollution (namely the voluntary pesticide and fertilizer reduction ratios); c. farmers' ecological compensation attitude; $d$. farmers' farmland conditions and environmental awareness. The basic information of farmers included family size, total family income, education level of the head of the household, age of the head of the household, whether the head of the household has other jobs, and the proportion of agricultural income in the total family income. The farmers' willingness to prevent and control agricultural non-point source pollution was measured by the voluntary pesticide and fertilizer reduction ratios. The farmers' ecological compensation attitude was measured by the minimum government compensation their required. The farmland conditions and environmental awareness of the farmers included whether they are or they have immediate relatives who are living in the water source areas, the cultivated land area, the degree of cultivated land fragmentation, whether they know their farmland is in the water source protection zone, and their evaluation of the pesticide/fertilizer's impact on the environment, etc.

The survey adopted the random sampling method, and the data were collected via face-to-face questionnaire survey. In the questionnaire, the voluntary pesticide and fertilizer reduction ratios and the corresponding willingness to accept compensation (compensation willingness) were processed by the DBDC model. When asking farmer respondents about their voluntary pesticide and fertilizer reduction ratios, the open questionnaire method was used at first, if the respondent cannot reply the question, then a few pre-set options were offered for them to make selections; the ratio options included: $10 \%, 20 \%, 30 \%, 40 \%, 50 \%$, and $100 \%$.

For the survey of the farmers' compensation willingness, an improved open DBDC was adopted to convert a certainproportion production loss estimated by the farmers into the cash amount, and this value was taken as the initial value when inquiring the respondents about whether they are willing to accept the compensation or not. If a respondent is willing to accept it, then, continue to ask whether he/she is willing to accept a lower price; if he/she is unwilling to accept it, then in the second-round, ask the respondent to give a higher compensation price. 100 was taken as the price step of the bid values, and this number was determined based on the response law of respondents in the pre-survey.

\section{DATA SOURCE AND ANALYSIS}

\subsection{Data source}

The research team took the summer vacation time in July 2019 to conduct random sampling surveys of rice farmers in 7 villages within the water source protection area of Siminghu Reservoir in Liangnong Town. 150 questionnaires were sent out for the first time, after screening, 124 valid questionnaires were retained. Then in September, 100 more questionnaires were sent out for the second time survey, and 94 valid questionnaires were returned. The total number of valid questionnaires was 218 .

\subsection{Sample characteristics}

The sample characteristics are shown in Table 1. Male respondents had accounted for $91.13 \%$, this was determined 
by two causes: first, since agricultural production is a production activity with high manual labor input, males are the main participants in agricultural production; second, for most families, the head of the household was mostly male, and they usually have the "decision-making power" in the house. The age of the respondents was relatively old; more than $80 \%$ of the respondents were above 50; the overall education level was low, respondents with a below elementary school education level accounted for $70.97 \%$; the family size was mostly middle size, households with a family member number between 3 and 5 accounted for $54.84 \%$; the income level was low, nearly $56.45 \%$ of the families' annual income was less than 70,000 yuan.

Table 1. Sample characteristics

\begin{tabular}{|c|c|c|c|c|c|c|c|}
\hline Question & Option & Number & Proportion & Question & Option & Number & Proportion \\
\hline \multirow[b]{2}{*}{ Gender } & Male & 200 & $91.13 \%$ & \multirow{6}{*}{$\begin{array}{c}\text { Education } \\
\text { level }\end{array}$} & Uneducated & 70 & $32.26 \%$ \\
\hline & Female & 18 & $8.06 \%$ & & $\begin{array}{l}\text { Below elementary } \\
\text { school }\end{array}$ & 30 & $13.71 \%$ \\
\hline \multirow{3}{*}{$\begin{array}{l}\text { Number of family } \\
\text { members }\end{array}$} & Less than 3 & 63 & $29.03 \%$ & & $\begin{array}{l}\text { Elementary school } \\
\text { graduate }\end{array}$ & 55 & $25.00 \%$ \\
\hline & $3-5$ & 120 & $54.84 \%$ & & Junior high graduate & 49 & $22.58 \%$ \\
\hline & More than 5 & 35 & $16.13 \%$ & & Senior high graduate & 9 & $4.03 \%$ \\
\hline \multirow{6}{*}{ Total family income } & $\begin{array}{c}\text { Less than } 10,000 \\
\text { yuan }\end{array}$ & 2 & $0.81 \%$ & & $\begin{array}{l}\text { College degree or } \\
\text { above }\end{array}$ & 5 & $2.42 \%$ \\
\hline & $\begin{array}{c}10,000-20,000 \\
\text { yuan }\end{array}$ & 16 & $7.26 \%$ & \multirow{5}{*}{ Age } & Below 40 & 2 & $0.81 \%$ \\
\hline & $\begin{array}{c}20,000-30,000 \\
\text { yuan }\end{array}$ & 21 & $9.68 \%$ & & $40-50$ & 35 & $16.13 \%$ \\
\hline & $\begin{array}{c}30,000-50,000 \\
\text { yuan }\end{array}$ & 47 & $21.77 \%$ & & $50-60$ & 72 & $33.06 \%$ \\
\hline & $\begin{array}{c}50,000-70,000 \\
\text { yuan }\end{array}$ & 37 & $16.94 \%$ & & $60-70$ & 90 & $41.13 \%$ \\
\hline & More than 70,000 & 95 & $43.55 \%$ & & Above 70 & 19 & $8.87 \%$ \\
\hline
\end{tabular}

\subsection{Statistical analysis}

\subsubsection{Distribution of voluntary pesticide/fertilizer reduction} ratios

The voluntary pesticide/fertilizer reduction ratios had been divided into six intervals for the respondents to choose from, namely: $[0 \%, 20 \%),[20 \%, 30 \%),[30 \%, 40 \%),[40 \%, 50 \%)$, $[50 \%, 100 \%), 100 \%$.

Except for interval $[50 \%, 100 \%)$, the respondents' choices were evenly distributed in the other five intervals. About $57 \%$ of the respondents chose that their voluntary fertilizer reduction ratio was less than $40 \%$. In terms of low fertilizer reduction ratios, the respondents did not show a particular preference for a certain ratio, which indicated that the output risk of fertilizer reduction was relatively controllable, and the farmers' sensitivity was relatively low.

In terms of pesticide reduction ratio, $82 \%$ of the respondents chose $100 \%$. This is because for farmers, compared with fertilizers, pesticides are a stronger output-related factor. In terms of a same reduction ratio, the reduction in pesticides would cause greater fluctuations in output than the reduction in fertilizers, and it could lead to unpredictable outcome. Many respondents chose to give up production and selected the $100 \%$ pesticide reduction ratio. A small number of respondents with rich production experience and enthusiasm for agriculture chose to consider reduce pesticide usage, but the pesticide reduction ratio they chosen was basically below $20 \%$.

3.3.2 Farmers' compensation willingness under different fertilizer reduction ratios

It can be found that, for respondents who's reported choice values of fertilize reduction were within the middle ranges of the options, the differences in their compensation willingness were relatively small; and for respondents who's reported choice values were concentrated at the two ends of ranges, the differences in their compensation willingness were relatively large (see Table 2). For respondents whose reported choice values were between $25 \%$ and $40 \%$, their attitudes for the output effects of fertilizers were relatively consistent; while for respondents who's reported choice values were lower, they can be divided into two types, one type was farmers who are optimistic about the influence of fertilize reduction on output, they chose low fertilize reduction ratios, and the compensation they asked was relatively low; the other type was farmers who are very pessimistic about fertilizer reduction, in their minds, even a small reduction in fertilizer usage would cause great output fluctuations, therefore, the compensation they asked was higher. For respondents who chose to completely reduce fertilizers, there're also differences in their opinions, one type thought that some output will still be retained and they're willing to continue the production, and their attitude towards compensation standards was more tolerant; the other type thought the output would be extremely low, it's not necessary to continue the production and they're willing to give up production and receive the compensation. Under the influence of these two different thoughts, the desired compensation range had been broadened greatly.

3.3.3 Farmers' compensation willingness under different pesticide reduction ratios

Although the distribution states were different, the statistics of pesticide reduction compensation also had some similar characteristics with that of the fertilizer reduction compensation (see Table 3 ). Since pesticides and fertilizers are not replaceable elements, we cannot compare the two. However, we can still judge from the characteristics of statistical data that whether it is pesticides or fertilizers, the farmer respondents had proposed their desired compensation amount based on the loss and income they calculated under the condition of pesticide and fertilizer reduction. 
Table 2. Characteristics of farmers' compensation willingness under different fertilizer reduction ratios

\begin{tabular}{ccccccc}
\hline Fertilizer reduction ratio & Frequency & Range & Minimum & Maximum & Mean & Standard deviation \\
\hline $10 \%$ & 53 & 600.00 & 0.00 & 600.00 & 235.60 & 146.34 \\
$20 \%$ & 44 & 700.00 & 0.00 & 700.00 & 248.32 & 179.14 \\
$25 \%$ & 5 & 100.00 & 300.00 & 400.00 & 340.00 & 52.92 \\
$30 \%$ & 23 & 300.00 & 200.00 & 500.00 & 327.62 & 98.12 \\
$40 \%$ & 5 & 336.00 & 0.00 & 336.00 & 192.00 & 173.07 \\
$50 \%$ & 16 & 510.00 & 190.00 & 700.00 & 390.67 & 156.69 \\
$100 \%$ & 16 & 565.00 & 435.00 & 1000.00 & 695.00 & 203.22 \\
\hline
\end{tabular}

Table 3. Characteristics of farmers' compensation willingness under different pesticide reduction ratios

\begin{tabular}{ccccccc}
\hline Pesticide reduction ratio & Frequency & Range & Minimum & Maximum & Mean & Standard deviation \\
\hline $10 \%$ & 19 & 700.00 & 100.00 & 800.00 & 416.36 & 208.56 \\
$16 \%$ & 2 & 0.00 & 0.00 & 0.00 & 0.00 & 0.00 \\
$17 \%$ & 2 & 0.00 & 285.00 & 285.00 & 285.00 & 0.00 \\
$20 \%$ & 11 & 440.00 & 200.00 & 640.00 & 423.33 & 181.29 \\
$40 \%$ & 2 & 0.00 & 253.00 & 253.00 & 253.00 & 0.00 \\
$50 \%$ & 4 & 480.00 & 320.00 & 800.00 & 560.00 & 339.41 \\
$100 \%$ & 179 & 1900.00 & 100.00 & 2000.00 & 790.75 & 253.28 \\
\hline
\end{tabular}

\section{INFLUENCING FACTORS ATTITUDES TOWARDS COMPENSATION \\ OF FARMERS' ECOLOGICAL}

\subsection{Variable selection}

In order to understand the response of farmers to the ecological compensation policy, this paper proposed an ecological compensation attitude index which was measured by the ratio of the farmer's minimum desired compensation amount for their reported voluntary fertilizer or pesticide reduction ratios (the compensation willingness) to their reported reduction ratios, it can be expressed as:

$$
A=\frac{C}{R}
$$

where, A represents the ecological compensation attitude towards fertilizers reduction (ATF) or pesticides reduction (ATP); C represents the farmers' minimum desired compensation amount for their reported voluntary fertilizer or pesticide reduction ratios (the compensation willingness); $\mathrm{R}$ represents the reported fertilizer or pesticide reduction ratios of the farmers.

According to the distribution state, the index values can be divided into four value ranges: $0,(0,1), 1,(1,+\infty)$. Solely based on the compensation proportion, the four ranges can be assigned with values from 1 to 4, and these four value ranges respectively represented the compensation willingness of different farmer groups for their environmental contributions: $1=$ Non-compensation; 2=Partial compensation; 3=Full compensation; 4=Excess compensation. Obviously, these four value ranges can also represent the compensation demand attitudes with a successive hierarchical relationship. If these four compensation demand attitudes were defined according to the intensity, then the non-compensation represents the weaker compensation demand attitude; the partial compensation represents the weak compensation demand attitude; the full compensation represents the strong compensation demand attitude; the excess compensation represents the stronger compensation demand attitude. The four value ranges represent increasingly intensive compensation demand attitudes. According to the common value assignment method, this paper adopted the value increase method. Therefore, the four value ranges had been redefined as: $1=$ weaker demand attitude (non-compensation); $2=$ weak demand attitude (partial compensation); $3=$ strong demand attitude (complete compensation); $4=$ stronger demand attitude (excess compensation) (see Table 4).

Table 4. Value assignment of dependent variables

\begin{tabular}{|c|c|c|c|}
\hline Range & $\begin{array}{c}\text { Compensation } \\
\text { willingness }\end{array}$ & $\begin{array}{c}\text { Compensation } \\
\text { attitude }\end{array}$ & Value \\
\hline 0 & Non-compensation & $\begin{array}{l}\text { Weaker demand } \\
\text { attitude }\end{array}$ & 1 \\
\hline$(0,1)$ & $\begin{array}{c}\text { Partial } \\
\text { compensation }\end{array}$ & $\begin{array}{l}\text { Weak demand } \\
\text { attitude }\end{array}$ & 2 \\
\hline 1 & $\begin{array}{l}\text { Complete } \\
\text { compensation }\end{array}$ & $\begin{array}{l}\text { Strong demand } \\
\text { attitude }\end{array}$ & 3 \\
\hline$(1,+\infty)$ & $\begin{array}{c}\text { Excess } \\
\text { compensation }\end{array}$ & $\begin{array}{l}\text { Stronger demand } \\
\text { attitude }\end{array}$ & 4 \\
\hline
\end{tabular}

Drawing on existing studies [4, 26-28] and combining with the actual situations of field survey, this paper determined 12 influencing factors of farmers' ecological compensation attitude: family size (FS), total family income (INCO), voluntary fertilizer/pesticide reduction ratios (FRR/PRR), education level of the head of the household (EDU), age of the head of the household (AGE), whether the head of the household has other jobs (OTHER), proportion of agricultural income in the total family income (POA), any immediate relatives living in the water source areas (RELAT), area of cultivated land (AREA), fragmentation of cultivated land (FRAGM), whether aware the farmland is in water source protection zone (AWARE), farmers' evaluation of the impact of pesticides/fertilizers on the environment (IOP/IOF).

\subsection{Model construction}

Since the dependent variables were ordinal variables, ordinal regression (ordinal outcome variable regression model) should be adopted for parameter estimation of the influencing factors. The basic formula of the model is: 


$$
\begin{aligned}
& \operatorname{link}\left[\varepsilon_{j}(\mathrm{x})\right]=\theta_{j}-\beta^{T} x \\
& =\theta_{j}-\left[\beta_{1} X_{1}+\beta_{2} X_{2}+\ldots+\beta_{\mathrm{i}} X_{i}\right]
\end{aligned}
$$

In the formula, link[] is the link function. There are five alternative link functions for the model, and the selection criteria are shown in Table 5.

Table 5. Link function types

\begin{tabular}{cc}
\hline Link function type & Application scenario \\
\hline Logit & Various types are evenly distributed \\
Complementary & High-level types are more likely to \\
log-log & appear \\
Negative log-log & Low-level types are more likely to appear \\
Probit & Normal distribution \\
Cauchit (inverse & Types at both ends are more likely to \\
Cauchy) & appear \\
\hline
\end{tabular}

Table 6. Frequencies of ecological compensation attitude towards fertilizers reduction in the four value ranges

\begin{tabular}{cccc}
\hline $\begin{array}{c}\text { Dependent } \\
\text { variable type } \\
\text { value }\end{array}$ & Frequency & $\begin{array}{c}\text { Effective } \\
\text { percentage }\end{array}$ & $\begin{array}{c}\text { Cumulative } \\
\text { percentage }\end{array}$ \\
\hline 1 & 14 & 6.4 & 6.4 \\
2 & 69 & 31.7 & 38.1 \\
3 & 84 & 38.5 & 76.6 \\
4 & 51 & 23.4 & 100.0 \\
Total & 218 & 100.0 & \\
\hline
\end{tabular}

Table 7. Frequencies of ecological compensation attitude towards pesticide reduction in the four value ranges

\begin{tabular}{cccc}
\hline $\begin{array}{c}\text { Dependent } \\
\text { variable type } \\
\text { value }\end{array}$ & Frequency & $\begin{array}{c}\text { Effective } \\
\text { percentage }\end{array}$ & $\begin{array}{c}\text { Cumulative } \\
\text { percentage }\end{array}$ \\
\hline 1 & 2 & 0.8 & 0.8 \\
2 & 58 & 26.6 & 27.4 \\
3 & 40 & 18.5 & 45.9 \\
4 & 118 & 54.1 & 100.0 \\
Total & 218 & 100.0 & \\
\hline
\end{tabular}

In this paper, the dependent variables had been classified into four ranges. According to Table 6, for the dependent variable ecological compensation attitude towards fertilizers reduction, its low-level appearance possibility was relatively low, and its high-level appearance possibility was higher, therefore, the complementary log-log function had been adopted for regression analysis. According to Table 7, for the dependent variable ecological compensation attitude towards pesticide reduction, this method had also been applied for parameter estimation.

\subsection{Empirical analysis of the influencing factors of ecological compensation attitude towards fertilizers reduction}

\subsubsection{Model fitting}

According to Table 8 , the Sig value of the chi-square test was far less than 0.01 , indicating that the final model was better than the model with intercept only; that is, the model was significantly valid.

According to Table 9, the probability value of the Pearson method was $0.169>0.05$; and the probability value of the deviation method was $0.998>0.05$, therefore, the model was considered to have a good goodness of fit.
Table 8. Model selection examination

\begin{tabular}{ccccc}
\hline Model & $\begin{array}{c}\mathbf{- 2} \text { log } \\
\text { likelihood }\end{array}$ & $\begin{array}{c}\text { Chi- } \\
\text { square }\end{array}$ & $\begin{array}{c}\text { Degree of } \\
\text { freedom }\end{array}$ & $\begin{array}{c}\text { Signific } \\
\text { ance }\end{array}$ \\
\hline $\begin{array}{c}\text { Intercept only } \\
\text { Final }\end{array}$ & 295.364 & & & \\
& 259.266 & 36.098 & 6 & 0.000 \\
\hline
\end{tabular}

Table 9. Model fitting examination

\begin{tabular}{cccc}
\hline & $\begin{array}{c}\text { Chi- } \\
\text { square }\end{array}$ & $\begin{array}{c}\text { Degree of } \\
\text { freedom }\end{array}$ & Significance \\
\hline Pearson method & 338.930 & 315 & 0.169 \\
Deviation method & 247.365 & 315 & 0.998 \\
\hline
\end{tabular}

In addition, in the measurement of Pseudo R-squared, the Cox and Snell $R^{2}$ value was 0.253 , Nagelkerke value was 0.275 , and the McFadden value was 0.117 , indicating that the explanatory variables selected in this paper were highly correlated with the explained variables (see Table 10).

Table 10. Measurement of Pseudo R-squared

\begin{tabular}{cc}
\hline Cox and Snell & 0.253 \\
\hline Nagelkerke & 0.275 \\
McFadden & 0.117 \\
\hline
\end{tabular}

\subsubsection{Analysis of influencing factors}

All variables had been input into the model for estimation, but the estimation results showed that only three variables' parameter estimation had passed the significance test. Therefore, this paper adopted stepwise regression to obtain the models with continuous improvements in the significance level of variable parameters, and Table 11 lists the estimation results of the 7 improvement models, and Model 7 had the best fitting result, the other 6 retained variables listed in the table had all passed the significance test under different levels of confidence.

6 factors that were mostly relevant to the compensation attitude were obtained in Model 7:

(1) Voluntary fertilizer reduction ratio was positively correlated with compensation attitude, that is, farmers with less reported choice values of fertilizer reduction ratio had stronger compensation willingness, which indicated that, although some farmers had the willingness to participate in ecological compensation, their demand levels of ecological compensation would not decrease due to their higher-level participation enthusiasm. This is because the farmers predicted their output risks based on their reported fertilizer and pesticide reduction ratios and asked for the corresponding compensations.

(2) Total family income was negatively correlated with compensation attitude, that is, higher income level farmers had a moderate attitude towards the compensation, indicating that if they have been provided with a lower level compensation, they are less likely to raise objections. On the contrary, farmers with a low income mainly rely on agricultural production for their living; therefore their attitude towards compensation was tougher.

(3) Family size was positively correlated with compensation attitude, that is, households with more family members generally had a higher requirement for compensation. Their food production was mainly self-sufficiency, and they calculated the compensation amount based on the food consumption of the family; therefore, households with more family members had a tougher attitude towards compensation. 
(4) Farmer's evaluation of the impact of fertilizers on environment was negatively correlated with compensation attitude, that is, among farmers who believed the fertilizers do have an impact on environment, the worse the impact they thought, the weaker the compensation attitude they have.

(5) Whether the farmers have other jobs was negatively correlated with compensation attitude. First, farmers having other jobs had a higher income level, and this can also be reflected in the relationship between total family income and compensation attitude. Second, farmers having other jobs had more opportunities to learn about the society, their broader visions made them have a better understanding of water source conservation, so they are more willing to cooperate with relevant policies. Third, farmers with other jobs have stronger employability, and land is no longer an indispensable means of production for their survival. Fourth, farmers with other jobs know better that non-agricultural employment can bring higher income levels than agricultural production; therefore, actually, they are more willing to spend more time on nonagricultural jobs, and only a low level compensation would satisfy them.

(6) Education level was negatively correlated with compensation attitude. Educated farmers tend to have stronger compensation attitude, it could be understood as their awareness of their compensation rights was stronger, and they are more protective of their rights than uneducated farmers. But meanwhile, educated farmers are more assertive in their response to compensation standards, and the changes in their initial reported choice values were smaller.

Table 11. Regression results of influencing factors of ecological compensation attitude towards fertilizers reduction

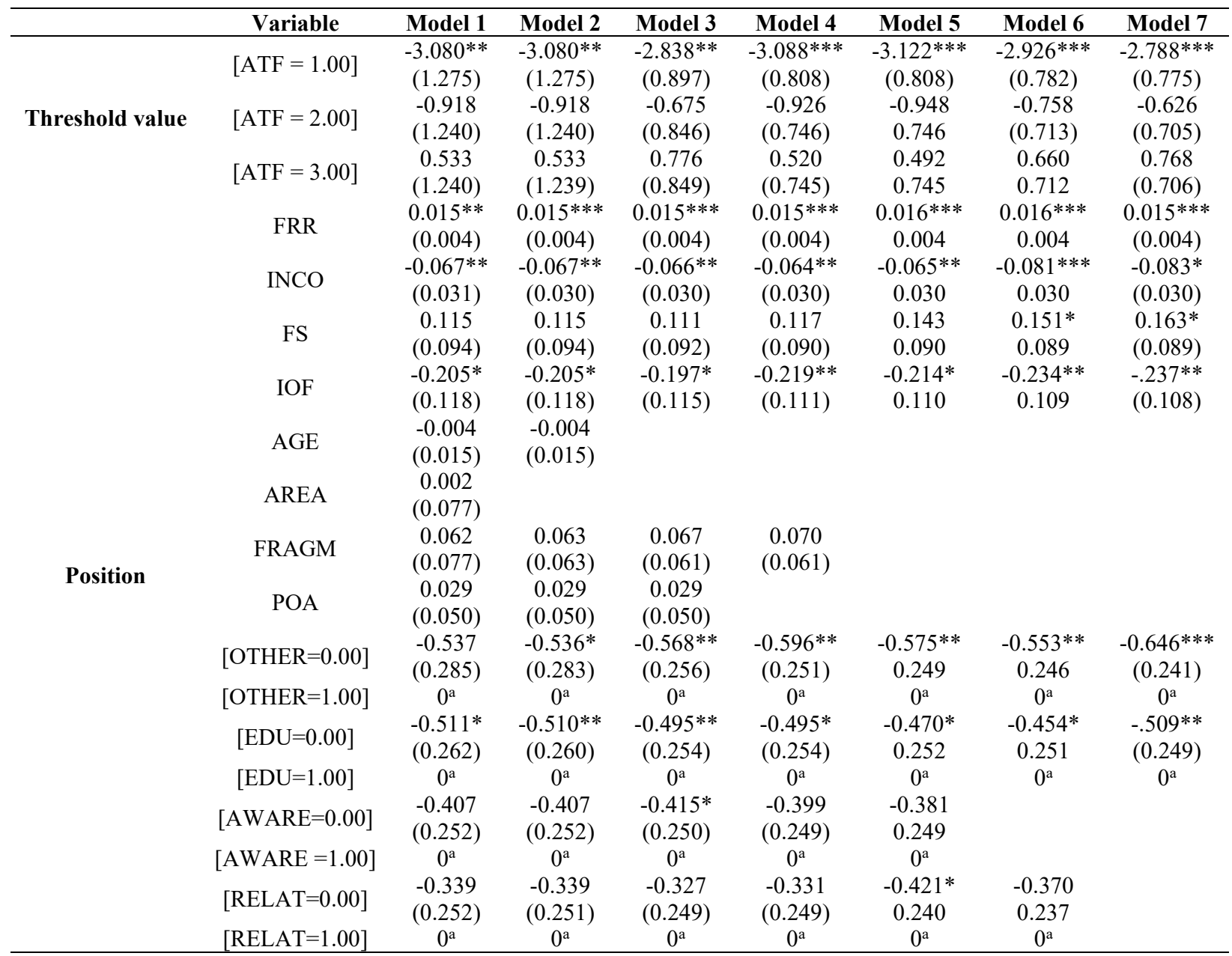

Note: "***", "**", and "*" respectively represent significant at the levels of $1 \%, 5 \%$, and $10 \%$.

\subsection{Empirical analysis of the influencing factors of ecological compensation attitude towards pesticide reduction}

Table 12 shows the regression results of the influencing factors of farmers' compensation attitude towards pesticide reduction. Only two independent variables of farmland fragmentation and whether they have immediate relatives living in water supply areas had shown significant correlations, wherein the degree of farmland fragmentation was positively correlated with the compensation attitude, and whether there're immediate relatives living in water supply areas was negatively corrected with it. The reason lies in that, farmers regard pesticides as a highly relevant factor for output, farmers' reduction willingness mainly concentrated in the high-level range, therefore, their compensation attitude were closer, many influencing factors had no significant effect, and their compensation attitude was more consistent. 
Table 12. Regression results of influencing factors of ecological compensation attitude towards pesticide reduction

\begin{tabular}{|c|c|c|c|c|c|c|c|c|c|}
\hline & Variable & Model 8 & Model 9 & Model 10 & & Variable & Model 8 & Model 9 & Model 10 \\
\hline \multirow{3}{*}{ Threshold } & {$[\mathrm{ATP}=1.00]$} & $\begin{array}{c}-5.435 \\
(1.704)\end{array}$ & $\begin{array}{l}-4.402 \\
(1.018)\end{array}$ & $\begin{array}{c}-5.144 * * * \\
(1.021)\end{array}$ & \multirow{10}{*}{ Position } & PRR & $\begin{array}{c}0.002 \\
(0.004)\end{array}$ & & \multirow{10}{*}{$\begin{array}{c}-0.493 * \\
(0.287) \\
0^{\mathrm{a}}\end{array}$} \\
\hline & {$[\mathrm{ATP}=2.00]$} & $\begin{array}{l}-1.722 \\
(1.389)\end{array}$ & $\begin{array}{l}-0.707 \\
(0.259)\end{array}$ & $\begin{array}{c}-1.455^{* * * *} \\
(0.264)\end{array}$ & & {$[\mathrm{EDU}=0.00]$} & $\begin{array}{l}-0.051 \\
(0.297)\end{array}$ & & \\
\hline & {$[\mathrm{ATP}=3.00]$} & $\begin{array}{l}-1.035 \\
(1.383)\end{array}$ & $\begin{array}{l}-0.043 \\
(0.240)\end{array}$ & $\begin{array}{c}-0.793 * * * \\
(0.238)\end{array}$ & & {$[\mathrm{EDU}=1.00]$} & $0^{\mathrm{a}}$ & & \\
\hline \multirow{7}{*}{ Position } & AGE & $\begin{array}{l}-0.002 \\
(0.019)\end{array}$ & \multirow{7}{*}{$\begin{array}{c}0.158^{* *} \\
(0.079)\end{array}$} & & & {$[\mathrm{OTHER}=0.00]$} & $\begin{array}{c}-0.342 \\
(0.331)\end{array}$ & & \\
\hline & FS & $\begin{array}{l}-0.076 \\
(0.110)\end{array}$ & & & & [OTHER=1.00] & $0^{\mathrm{a}}$ & & \\
\hline & INCO & $\begin{array}{l}-0.037 \\
(0.036)\end{array}$ & & & & {$[$ RELAT $=0.00]$} & $\begin{array}{l}-0.339 \\
(0.313)\end{array}$ & & \\
\hline & FRAGM & $\begin{array}{c}0.106 \\
(0.098)\end{array}$ & & & & {$[$ RELAT $=1.00]$} & $0^{\mathrm{a}}$ & & \\
\hline & AREA & $\begin{array}{c}0.066 \\
(0.138)\end{array}$ & & & & {$[\mathrm{AWARE}=0.00]$} & $\begin{array}{c}-0.054 \\
(0.310)\end{array}$ & & \\
\hline & POA & $\begin{array}{c}0.061 \\
(0.055)\end{array}$ & & & & {$[\mathrm{AWARE}=1.00]$} & $0^{\mathrm{a}}$ & & \\
\hline & IOP & $\begin{array}{l}-0.160 \\
(0.121)\end{array}$ & & & & & & & \\
\hline
\end{tabular}

\section{CONCLUSION AND ENLIGHTENMENT}

\subsection{Conclusion}

This paper found that although the distributions of voluntary fertilizer and pesticide reduction ratios were different, the statistical results of the compensation attitude toward fertilizer and pesticide reduction showed certain similarities. Farmers whose voluntary reduction ratio was in the middle level had more conservative compensation attitude, while those whose voluntary reduction ratio was in the two ends had very different compensation attitudes, indicating that most farmers have a modest attitude towards the problem of government payments. Then, the paper adopted ordinal regression to analyze the influencing factors of the farmers' ecological compensation attitude towards fertilizers reduction and the results showed that, voluntary fertilizer reduction ratio and family size were positively correlated with compensation attitude; total family income and other 4 influencing factors were negatively correlated with compensation attitude. The analysis of the influencing factors of farmers' ecological compensation attitude towards pesticide reduction suggested that the action direction of the statistically significant variables of pesticide reduction was consistent with that of the fertilizer reduction, which also further proved the reliability of the empirical results. At the same time, the farmers' compensation attitudes towards strong output-related factors were relatively consistent, while their compensation attitudes towards weak output-related factors were heterogeneous.

\subsection{Enlightenment}

\subsubsection{Enlightenment for compensation mechanism}

(1) Strengthen ecological compensation policies for farmers

Although current water source area ecological protection policy documents had listed pesticide and fertilizer reduction as a goal of environmental governance, no strict and clear implementation plans and measures have been formulated yet. The government should include specific control measures and compensation methods for farmland non-point source pollution in the ecological compensation framework of the water source areas, so as to prevent continuous deterioration of ecological environment.

(2) Implement the compensation ideas with farmers' willingness as the orientation

The government should implement strict ecological compensation supervision systems to prevent situations such as insufficient subsidies or un-fulfillment of promises, so as to enhance the credibility of policies. At the same time, the government should pay attention to the livelihood of farmers, understand their needs, give more cares to farmers who have sacrificed their own interests for protecting the environment, and provide farmers with material and psychological protection, so that they can actively participate in the protection of water sources.

\subsubsection{Enlightenment for compensation methods}

(1) Social plan: actively provide job opportunities

The government should take cash compensation as the main method and supplement other compensation forms to improve farmers' satisfaction with the compensation. One feasible solution is that, besides formulating a common compensation standard according to the average farmland output in the water source areas, the government can provide other job opportunities for farmers who are willing to do part-time jobs.

(2) Public plan: enhance farmers' awareness of participation

The government could organize a negotiation team consisted of party members and educated farmers to discuss issues such as the basic compensation standard, so that they could actively play their roles in compensation policy negotiation, clearly explain the feasibility of policy implementation and farmer participation based on farmers' interests, and thus lowering survey costs, improving survey efficiency, and enhancing policy effectiveness. At the same time, enhancing farmers' awareness of the harm brought by their behaviors to the environment can encourage them to participate in environmental protection and lower the policy costs, therefore, it's necessary to promote the education and publicity works to enhance people's awareness for water environment protection. Government can use multiple media 
such as broadcast, television and posters to promote the environmental significance of accurate and scientific planting, also, the influence of civil organizations could be borrowed to mobilize farmers to participate in comprehensive farmland management.

(3) Technical plan: promote new green technologies

In addition to the above-mentioned measures, a more feasible solution is to provide advanced green agricultural technologies for farmers who wish to continue agricultural production works. Subsidies could be provided for some green measures (such as insecticidal lamps, sticky traps and other pesticidal tools that can replace pesticides), and some green technologies can be promoted in villages (such as biological pesticides and soil testing and formulated fertilization), so as to reduce water source pollution while improving the utilization efficiency of fertilizers and pesticides. By constantly providing preferential policies for large-scale growers and then gradually extending these benefits to smallscale growers, and then to all farmers who are willing to engage in planting works, the farmers' farmland management ability could be improved comprehensively.

\section{ACKNOWLEDGMENT}

This work is supported by Project of the Zhejiang Soft Science Research Plans (Grant No.: 2020C35019), Water Culture Research Program of Zhejiang University of Water Resources and Electric Power (Grant No.: SWH201802).

\section{REFERENCES}

[1] Davies, E.G., Simonovic, S.P. (2011). Global water resources modeling with an integrated model of the social-economic-environmental system. Advances in Water Resources, 34(6): 684-700. https://doi.org/10.1016/j.advwatres.2011.02.010

[2] Yao, L., Shi, Z.T., Liu, X.Y. (2009). Kunming Songhuaba water source area population and ecological environment question research. Environmental Science and Management, 34(1): 135-138. https://doi.org/10.3969/j.issn.1673-1212.2009.01.037

[3] Wohlfart, C., Kuenzer, C., Chen, C., Liu, G. (2016). Social-ecological challenges in the Yellow River basin (China): A review. Environmental Earth Sciences, 75(13): 1066. https://doi.org/10.1007/s12665-016-58642

[4] Ju, X., Gu, B., Wu, Y., Galloway, J.N. (2016). Reducing China's fertilizer use by increasing farm size. Global Environmental Change, 41: 26-32. https://doi.org/10.1016/j.gloenvcha.2016.08.005

[5] Liu, K., Qi, Z.H., Huang, W.H., Ye, S.H. (2019). Research on the influence of capital endowment heterogeneity on farmers' ecological production: analysis from horizontal and structural perspectives. China Population Resouces and Environment, 29(2): 87-96. https://doi.org/10.12062/cpre.20181023

[6] Rezaei, R., Safa, L., Damalas, C.A., Ganjkhanloo, M.M. (2019). Drivers of farmers' intention to use integrated pest management: Integrating theory of planned behavior and norm activation model. Journal of Environmental Management, 236: 328-339.

[7] Berbel, J., Martin-Ortega, J., Mesa, P. (2011). A cost- effectiveness analysis of water-saving measures for the water framework directive: The case of the Guadalquivir River Basin in Southern Spain. Water Resources Management, 25(2): 623-640. https://doi.org/10.1007/s11269-010-9717-6

[8] Shi, Z.H., Cui, M., Zhang, H. (2020). Study on farmers' green production willingness based on expanded planning behavior theory. Journal of Arid Land Resources and Environment, 34(3): 4048. https://doi.org/10.13448/j.cnki.jalre.2020.64

[9] Kobayashi, Y., Higa, M., Higashiyama, K., Nakamura, F. (2020). Drivers of land-use changes in societies with decreasing populations: A comparison of the factors affecting farmland abandonment in a food production area in Japan. PloS One, 15(7): e0235846. https://doi.org/10.1371/journal.pone.0235846

[10] Farley, K.A., Bremer, L.L. (2017). "Water is life": Local perceptions of páramo grasslands and land management strategies associated with payment for ecosystem services. Annals of the American Association of Geographers, 107(2): 371-381. https://doi.org/10.1080/24694452.2016.1254020

[11] Reimer, A., Thompson, A., Prokopy, L.S., Arbuckle, J. G., Genskow, K., Jackson-Smith, D., Nowak, P. (2014). People, place, behavior, and context: A research agenda for expanding our understanding of what motivates farmers' conservation behaviors. Journal of Soil and Water Conservation, 69(2): 57A-61A.

[12] Stern, P.C., Dietz, T. (1994). The value basis of environmental concern. Journal of Social Issues, 50(3): 65-84. https://doi.org/10.1111/j.15404560.1994.tb02420.x

[13] Timsina, J. (2018). Can organic sources of nutrients increase crop yields to meet global food demand. Agronomy, $\quad 8(10)$ : 214. https://doi.org/10.3390/agronomy8100214

[14] Zhao, X.Y., Xu, Z.M. (2009). Analysis framework and applications prospect of payments for environmental services. China Population Resouces and Environment, 19(4): 112-118. https://doi.org/10.3969/j.issn.10022104.2009.04.021

[15] Salzman, J., Bennett, G., Carroll, N., Goldstein, A., Jenkins, M. (2018). The global status and trends of Payments for Ecosystem Services. Nature Sustainability, 1(3): 136-144. https://doi.org/10.1038/s41893-0180033-0

[16] Hysing, E., Lidskog, R. (2018). Policy contestation over the ecosystem services approach in Sweden. Society \& Natural Resources, 31(4): 393-408. https://doi.org/10.1080/08941920.2017.1413719

[17] Schröder, N.J.S. (2019). IWRM through WFD implementation? Drivers for integration in polycentric water governance systems. Water, 11(5): 1063. https://doi.org/10.3390/w11051063

[18] Dong J, Wu D. (2020). An evaluation of the impact of ecological compensation on the cross-section efficiency using SFA and DEA: A case study of Xin'an River basin. Sustainability, 12(19): 7966. https://doi.org/10.3390/su12197966

[19] Mehring, M., Zajonz, U., Hummel, D. (2017). Socialecological dynamics of ecosystem services: livelihoods and the functional relation between ecosystem service supply and demand-evidence from Socotra Archipelago, Yemen and the Sahel Region, West Africa. 
Sustainability,

9(7):

1037.

https://doi.org/10.3390/su9071037

[20] Feng, D., Wu, W., Liang, L., Li, L., Zhao, G. (2018). Payments for watershed ecosystem services: Mechanism, progress and challenges. Ecosystem Health and Sustainability, $4(1)$ : 13-28. https://doi.org/10.1080/20964129.2018.1434318

[21] Xu, T., Zhao, M.J., Li, E.H., Qiao, D. (2018). The impact of technology perception and subsidy policy on different phases of farmers water-saving irrigation technology adoption. Resources Science, 40(4): 809-817. https://doi.org/10.18402/resci.2018.04.14

[22] Xu, T., Qiao, D., Yan, Y., Ni, Q., Zhao, M.J. (2019) Farmers' preferences of agricultural subsidy of policy attributes and their marginal rate of substitution-Taking drip irrigation as an example. Journal of Arid Land Resources and Environment, 33(12): 48-53. https://doi.org/10.13448/j.cnki.jalre.2019.345

[23] Zhang, L.Q. (2011). Eco-compensation standard for small watershed by various evaluation methods: A case study of Qiupu river in Anhui province. Journal of Northeast Forestry University, 39(10): 124-128. https://doi.org/10.3969/j.issn.1000-5382.2011.10.035

[24] Sun, B., Duan, W., Ding, M.H., Feng, Y., Wen, Y.L. (2017). Preference analysis of household ecological compensation in Crested Ibis protected area in Hanzhong, Shaanxi based on choice experiments. Resources Science, 39(9): 1792-1800. https://doi.org/10.18402/resci.2017.09.16

[25] Li, W.Y., Zhang, Y.H., Wang, H., Zhu, C.M., Xu, B.G. (2018). Preference analysis of rural households' compensation pattern to farmland protection. China Land Science, $32(7)$ : 42-48. https://doi.org/10.11994/zgtdkx.20180625.093634

[26] Knowler, D., Bradshaw, B. (2007). Farmers' adoption of conservation agriculture: A review and synthesis of recent research. Food Policy, 32(1): 25-48. https://doi.org/10.1016/j.foodpol.2006.01.003

[27] Chang, Q., Li, X.P., Xie, X.X., Zhao, M.J. (2020). The impact of non-agricultural employment on farmers' ecological production behavior: Based on the mediating effect of agricultural production and operation characteristics and the regulating effect of the family life cycle. China Rural Survey, 2020(1): 76-93.

[28] Atinkut, H.B., Yan, T., Arega, Y., Raza, M.H. (2020). Farmers willingness-to-pay for eco-friendly agricultural waste management in Ethiopia: A contingent valuation. Journal of Cleaner Production, 261: 121211. https://doi.org/10.1016/j.jclepro.2020.121211 